\title{
SPELEOMYCOLOGY OF AIR IN DEMÄNOVSKÁ CAVE OF LIBERTY (SLOVAKIA) AND NEW AIRBORNE SPECIES FOR FUNGAL SITES
}

\author{
Rafał Ogórek
}

\begin{abstract}
The study is the first report of the fungal air quality in the Demänovská Cave of Liberty, Slovakia, which is one of the most visited caves in Slovakia (Low Tatras). A total of 108 air samples were collected in June 2014 using the microbiological air sampler "Air Ideal 3P" and Potato Dextrose Agar medium. Fungi were identified based on phenotypic tests and ITS regions analysis. Air samples collected from underground sites contained fewer propagules of fungi (from 86.7 to 126.7 colony-forming units per $\mathrm{m}^{3}$ of air) than outdoor air samples (391.7). Altogether, the incidence of $18 \mathrm{different}$ fungal species were found in the air of the cave, and most of them were isolated from the indoor samples. Cladosporium macrocarpum spores dominated in this study. The fungal species such as Bjerkandera adusta, Exophiala xenobiotica, Fusarium lateritium, Penicillium aurantiacobrunneum, and Trichoderma citrinoviride were detected for the first time in the internal air of underground sites. Overall, fungal air quality of the Demänovská Cave does not pose a biological threat to people and animals with undamaged immune systems according to most standards of fungal sir contamination. However, some of the airborne fungi detected in the cave can pose a risk to persons and animals with weakened immune systems or people who have fungal allergies.
\end{abstract}

\section{Introduction}

The earth's atmosphere has a great impact on the quality of life, especially in these times when the air quality has dropped significantly (Bruce et al., 2000; Darçın, 2014). However, Hippocrates mentioned in the Corpus Hippocraticum manuscript that some of the air components can be the cause of human illness (Mammas and Spandidos, 2016). Assessment of outdoor and indoor air pollution of buildings and public places is more frequent than underground sites. Poor indoor air quality of buildings can affect the deterioration of the health of residents such as skin and respiratory problems, poisoning, malaise and general weakness (Stolwijk, 1991; Romagnoli et al., 2016). The problem of poor indoor air quality is very serious and it can affect up to 3 billion people worldwide. The term "sick building syndrome" (SBS) was introduced in 1983 to describe the situation where a building affects human health (WHO, 1983). Moreover, it should be emphasized that microscopic fungi and their secondary metabolites (i.e. mycotoxins) play a major role in SBS. The fungal spores can constitute up to $70 \%$ of all bioaerosol pollution of indoor air (Brickus et al., 1998; Reynolds et al., 2001).

Atmospheric air and subterranean ecosystems are among the most inhospitable habitats for mycobiota, mainly due to lack of nutrients, and in the case of underground sites, also due to low temperatures (Poulson and White, 1969). Consequently, fungi usually occur as spores suspended in the air in these environments, which are also reproductive dispersal structures (Barton and Northup, 2007; Kokurewicz et al., 2016). On the other hand, environmental stress is one of the main factors determining evolution; and therefore, fungi that can tolerate or adapt to unfavorable living conditions in the underground are usually extremophile species (Rampelotto, 2013). These species most often have a high potential to secrete various biologically active compounds that, among others, may pose a risk to human and animal health, e.g. mycotoxins (Barton and Northup, 2007; Zain, 2011).

Natural and artificial underground ecosystems are mainly the place of occurrence of fungi belonging to the phylum Ascomycota (Vanderwolf, et al., 2013). In the summer, fungi of the genera Cladosporium usually dominate underground sites, and Penicillium species in the winter (Pusz et al., 2015; Ogórek et al., 2017). Currently, 44 genera of airborne fungi have been detected in Slovakian caves, and most species belong to the Penicillium (Nováková, 2009; Ogórek et al., 2016 a, b, c, d; 2018). Moreover, Penicillium species are significantly related to increased incidence of SBS, allergic respiratory diseases, and they can also cause opportunistic mycosis in humans and animals (Eschete et al., 1981; Hoffman et al., 1992; Pekkanen et al., 2007). Thus, it is important to do mycological monitoring of air in underground habitats, especially in the case of tourist facilities and/or those used by hibernating bats.

The main goal of this research was to assess the fungal air quality during summer in Demänovská Cave of Liberty, which is open to tourists, by determining the number and species composition of cultivable, microscopic fungi in the air of this cave. Additionally, we wanted to check: (1) whether the mycological quality of air within the investigated underground sites poses a risk to the health of workers and tourists, and (2) influence of air temperature and humidity on the concentration of fungal spores in the air.

University of Wroclaw, Institute of Genetics and Microbiology, Department of Genetics, Przybyszewskiego Street 63/77, 51-148 Wroclaw, Poland, E-mail: rafal-ogorek@wp.pl, 


\section{Material and Methods}

\section{Description of the study area}

The study was carried out in the Demänovská Cave of Liberty, "Demänovská jaskyňa slobody" (4899'8" N, 1958'5" E), which is part of the biggest cave system in Slovakia - the Demänová Caves system (Fig. 1). The cave passages are $8126 \mathrm{~m}$ long, and its entrance lies at an elevation of $870 \mathrm{~m}$ a.s.I. It is formed in the Middle Triassic, dark-gray Gutenstein limestones of the Križna Nappe, along the tectonic faults. These faults are shaped by corrosive and erosive activity of ponor allochthonous water flows of the Demänovká River and its tributaries (Marušin, 2003). Currently, the cave is inhabited by four species of bats, with the most frequent being the greater mouse-eared bat (Myotis Borkhausen) and the whiskered bat (Myotis mystacinus Kuhl) (Slovak Caves Administration, 2018). According to Nudziková (2014), this cave is the most visited underground facility in Slovakia, e.g. it is estimated that 111,261 tourists visited the caves in 2014. However, there are no reports about mycological air quality in this cave.

\section{Air sampling}

The air samples were collected on June 5, 2014 from indoor and outdoor air of the cave (Fig. 1), using the microbiological air sampler "Air Ideal 3P" (bioMérieux), and Potato Dextrose Agar (PDA, Biocorp) (Ogórek et al., 2013). It was programmed for air sample volumes of $50 \mathrm{~L}, 100 \mathrm{~L}$, and $150 \mathrm{~L}$, and the measurement in particular sampling sites was performed in six-plicate for each volume. Additionally, the air temperature and relative humidity were measured nine times at each sampling site, using a LB-522 thermohygrometer (Label, accuracy: $\pm 1 \%$ ). The air samples in Petri dishes with PDA were incubated from 4 to 21 days at $25 \pm 1{ }^{\circ} \mathrm{C}$. After incubation, the colonies that appeared on the medium
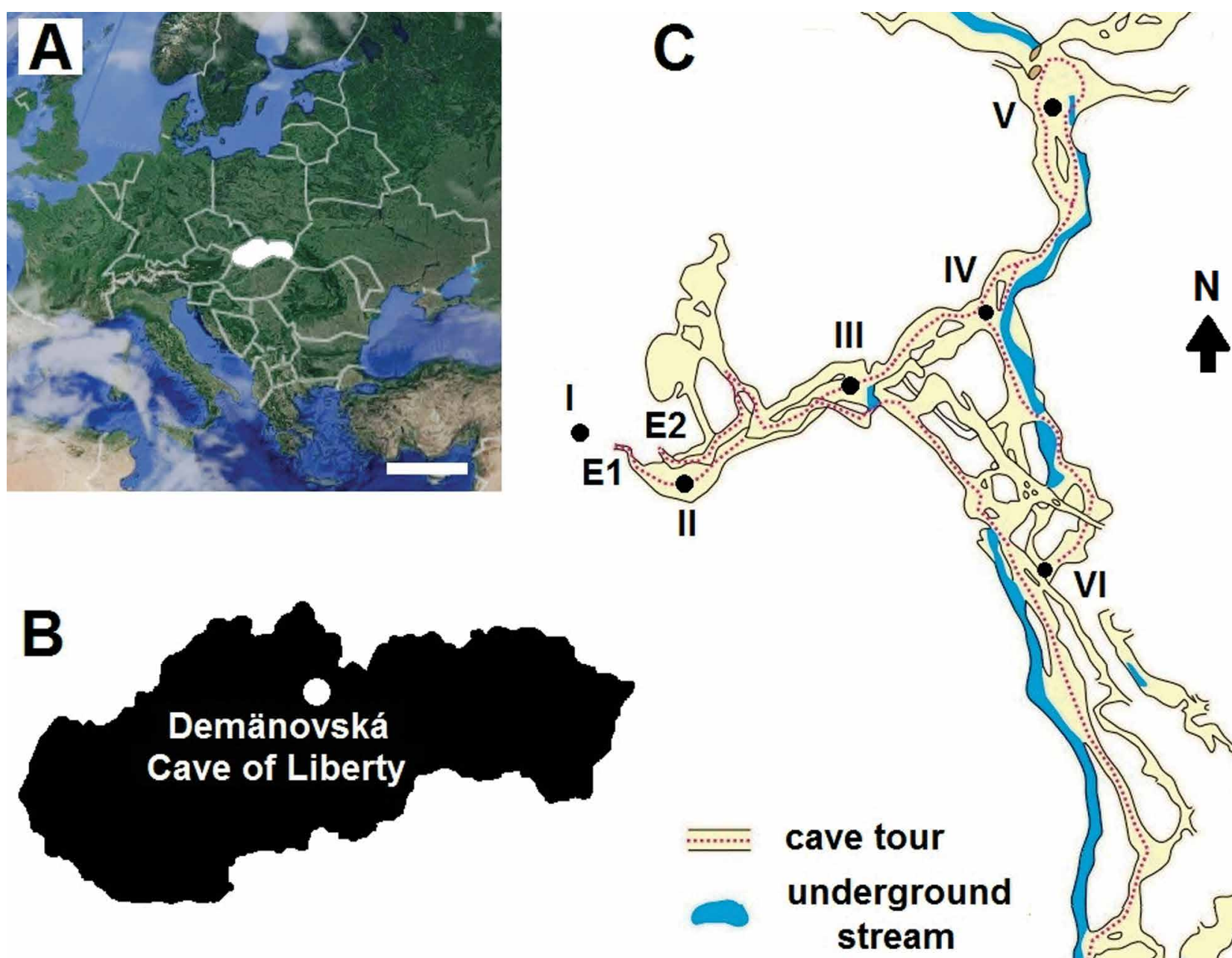
stream

Figure 1. Geographic location of Slovakia $(A)$ and Demänovská Cave of Liberty (B). Sampling location (C) on the tourist route: E1 entrance to the cave, E2 - exit from the cave, I - sampling location outside the cave, from II to VI - sampling locations inside the cave. Scale bars: $A=500 \mathrm{~km}, B=100 \mathrm{~km}, C=100 \mathrm{~m}$. 
were counted. The colony-forming unit concentrations were expressed as CFU per cubic meter of air using the formula $X=(a \times 1000) / V$, where $a$ is the number of colonies obtained on a Petri dish, and $V$ is the air volume sampled $\left(\mathrm{m}^{3}\right)$. Then, fungal colonies were subcultured on PDA medium for phenotypic and molecular identification.

\section{Morphological and molecular identification}

Overall, fungal structures were observed on PDA, and additionally on Malt Extract Agar (MEA, Biocorp), Czapek-Dox Agar (1.2\% agar, Biocorp), and Czapek Yeast Autolysate Agar (CYA) for Penicillium and Aspergillus. Then, fungi were identified using the taxonomic literature (Jülich, 1979; Golubev, 1981; Tanaka et al., 2001; Frisvad and Samson, 2004; Keirle et al., 2004; Chilvers and du Toit, 2006; de Hoog et al. 2006; Houbraken et al., 2011; Vitale et al., 2011; Bensch et al., 2012; Jung et al., 2014; Visagie et al., 2014; Hernández-Restrepo et al., 2016; Kim et al., 2016). DNA was isolated from fungal colonies cultured on PDA according to the original, hexadecyltrimethylammonium bromide- (CTAB) based method (Doyle and Doyle, 1987), modified as described by Ogórek et al. (2012). The internal, transcribed spacer region of fungal rDNA was amplified using the primer ITS1 (5'-TCCGTAGGTGAACCTGCGG-3') and ITS4 (5'-TCCTCCGCTTATTGATATGC-3') (White et al., 1990). Polymerase chain reactions were performed in a T100 Thermal Cycler (Bio-Rad), according to Ogórek et al. (2016a). The PCR products were verified by electrophoretic separation on the gel of $1.2 \%$ agarose. Then, they were purified by using Clean-UP (A\&A Biotechnology) and sequenced by Macrogen Europe (Netherlands).

\section{Data analyses}

BioEdit Sequence Alignment Editor was used for the analysis of the obtained fungal ITS sequences (http://www. mbio.ncsu.edu/bioedit/bioedit.html). Next, fungi were identified to species by using the BLAST algorithm (http://www. ncbi.nlm.nih.gov/), that compared the obtained sequences with those deposited in the GenBank database. The sequences were placed in GenBank databases (Table 1). The data from the number of airborne fungal colonies were subjected to statistical analysis by using a Statistica 12.0 package. For this purpose, one-way analysis of variance

Table 1. Airborne fungi detected in the Demänovská Cave of Liberty and results of BLAST (all E values were zero). A + indicates that the fungus was cultured from the air samples.

\begin{tabular}{|c|c|c|c|c|c|c|c|c|}
\hline \multirow[b]{3}{*}{1} & \multirow{3}{*}{$\begin{array}{c}\text { Fungi } \\
\text { Aspergillus elegans Gasperini }\end{array}$} & \multicolumn{2}{|c|}{ Air } & \multicolumn{4}{|c|}{ Identity with Sequence from GenBank } & \multirow{3}{*}{$\begin{array}{c}\text { GenBank } \\
\text { Accession No. } \\
\text { KX426973.1 }\end{array}$} \\
\hline & & \multirow[t]{2}{*}{ Outside } & \multirow{2}{*}{$\frac{\text { Inside }}{+}$} & \multirow[t]{2}{*}{ Accession } & \multirow{2}{*}{$\begin{array}{c}\text { Query } \\
\text { Cover, \% } \\
\text { FM201287.1 }\end{array}$} & \multicolumn{2}{|l|}{ Identity, \% } & \\
\hline & & & & & & 97 & 99 & \\
\hline 2 & A. flavus Link & & + & & LN482443.1 & 99 & 99 & KX426971.1 \\
\hline 3 & A. niger Tiegh. & & + & & KP940595.1 & 100 & 99 & KX426976.1 \\
\hline 4 & Bjerkandera adusta (Willd.) P. Karst. & + & + & & FJ228211.1 & 98 & 99 & KX426963.1 \\
\hline 5 & Botrytis cinerea Pers. & + & & & KP151610.1 & 98 & 99 & KX426964.1 \\
\hline 6 & $\begin{array}{l}\text { Cladosporium cladosporioides (Fresen.) } \\
\text { G.A. de Vries }\end{array}$ & & + & & KJ589547.1 & 98 & 88 & KX426970.1 \\
\hline 7 & C. macrocarpum Preuss 1848 & + & + & & KM977762.1 & 98 & 99 & KX426960.1 \\
\hline 8 & $\begin{array}{l}\text { Coprinellus disseminatus (Pers.) J.E. } \\
\text { Lange } 1938\end{array}$ & + & & & JN159561.1 & 97 & 100 & KX247294.1 \\
\hline 9 & $\begin{array}{l}\text { Cutaneotrichosporon curvatus (Diddens } \\
\text { \& Lodder) A.M. Yurkov, X.Z. Liu, F.Y. } \\
\text { Bai, M. Groenew. \& Boekhout }\end{array}$ & & + & & NR_130657.1 & 99 & 99 & KX426975.1 \\
\hline 10 & Discosia sp. & + & + & & KU325138.1 & 90 & 96 & KX426977.1 \\
\hline 11 & $\begin{array}{l}\text { Exophiala xenobiotica de Hoog, J.S. } \\
\text { Zeng, Harrak \& Deanna A. Sutton }\end{array}$ & & + & & KJ522804.1 & 96 & 99 & KX426972.1 \\
\hline 12 & Fusarium lateritium Nees & + & + & & JN391185.1 & 99 & 99 & KX426966.1 \\
\hline 13 & $\begin{array}{l}\text { Microdochium seminicola M. Hern.- } \\
\text { Restr., Seifert, Clear \& B. Dorn }\end{array}$ & + & + & & KP859023.1 & 98 & 99 & KX426969.1 \\
\hline 14 & $\begin{array}{l}\text { Penicillium aurantiacobrunneum } \\
\text { Houbraken, Frisvad \& Samson }\end{array}$ & + & + & & NR_121509.1 & 97 & 99 & KX426962.1 \\
\hline 15 & P. brevicompactum Dierckx & + & + & & KT876695.1 & 100 & 99 & KX426968.1 \\
\hline 16 & P. crustosum Thom & & + & & HQ850913.1 & 97 & 82 & KX426967.1 \\
\hline 17 & Phlebiopsis gigantea (Fr.) Jülich & + & & & KP676120.1 & 97 & 99 & KX426965.1 \\
\hline 18 & Trichoderma citrinoviride Bissett & & + & & JX125617.1 & 97 & 99 & KX426974.1 \\
\hline & $\sum$ species & 10 & 15 & & & $\cdots$ & & \\
\hline
\end{tabular}


(ANOVA) and the Tukey HSD (honest significant differences) test at $\alpha \leq 0.05$ were used. The Pearson correlation coefficient $r$ was used to determine the relation between the temperature and humidity of the air and the concentrations of airborne fungal propagules.

\section{Results and Discussion}

The results of this study show that the indoor air temperature $\left(6.8-8.5^{\circ} \mathrm{C}\right)$ of the examined cave in the summer was

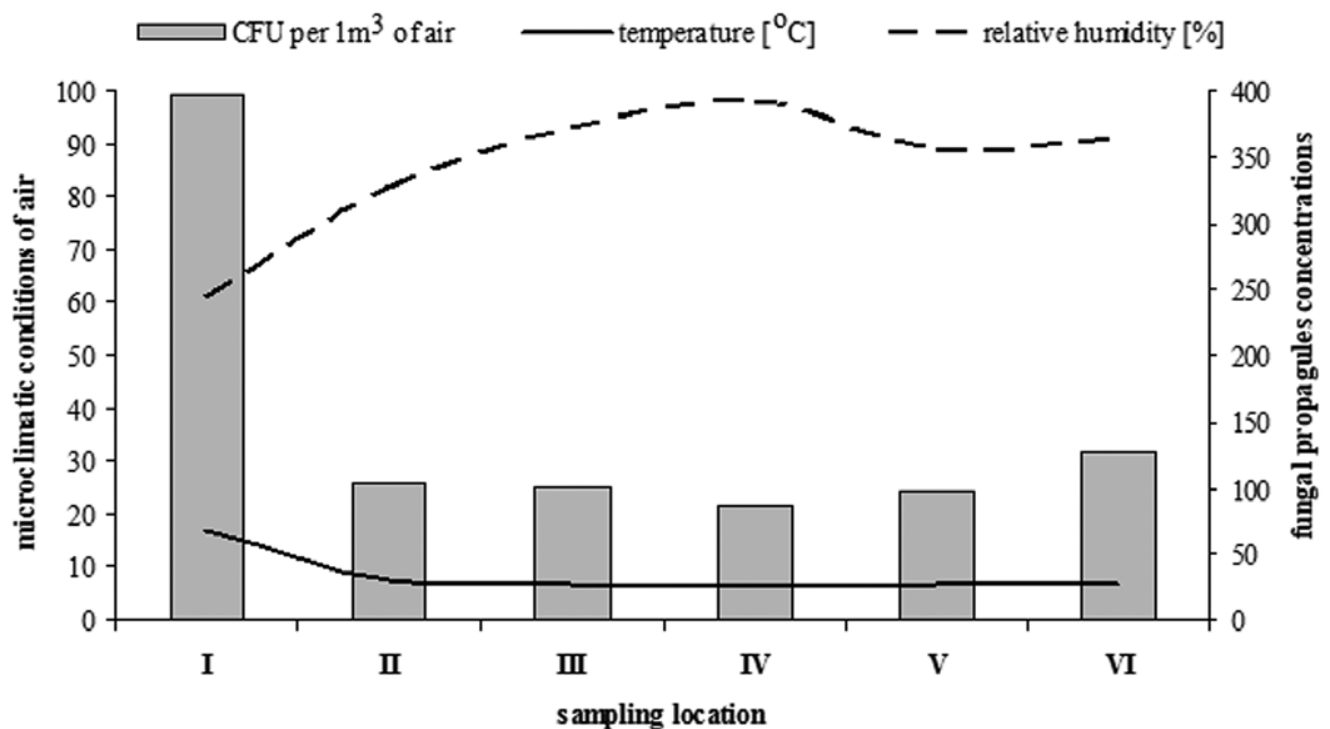

Figure 2. The climate parameters and measured concentrations of airborne fungal propagules at the sampled locations in the Demänovská Cave of Liberty: location I - outside the cave, locations from II to $\mathrm{VI}$ - inside the cave. lower than the outdoor air $\left(16.9{ }^{\circ} \mathrm{C}\right)$ and correlated positively with the concentration of airborne fungal propagules $(p<0.05$, $r=0.98$ ). A similar situation was not reported for relative humidity of the air, which was lower outside the cave $(61.1 \%)$ than inside $(81.7-98 \%)$ (Table 2, Fig. 2). According to Tang (2009), these factors most affect the survival of fungi in the environment. However, the survival of mycobiota in the air also depends on other factors that were not measured in these studies, such as ultraviolet radiation, pres-

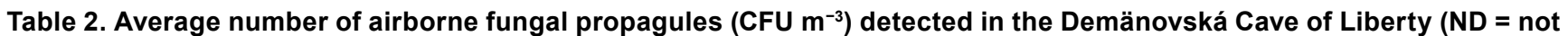
detected).

\begin{tabular}{|c|c|c|c|c|c|c|}
\hline \multirow[b]{2}{*}{ Fungi } & \multicolumn{6}{|c|}{ Sampling Location } \\
\hline & la & II & III & IV & $\mathbf{V}$ & VI \\
\hline Aspergillus elegans & ND & ND & $10.1 \mathrm{a}$ & ND & ND & ND \\
\hline A. flavus & ND & $16.7 \mathrm{abc}$ & $15.0 \mathrm{a}$ & $11.7 a b$ & $15.0 \mathrm{abc}$ & $8.3 \mathrm{a}$ \\
\hline A. niger & ND & ND & $23.4 \mathrm{a}$ & $20.0 \mathrm{ab}$ & $25.0 \mathrm{ab}$ & $28.3 \mathrm{a}$ \\
\hline Bjerkandera adusta & $63.0 \mathrm{~b}^{* *}$ & $26.7 \mathrm{ab}$ & $18.3 \mathrm{a}$ & $11.7 a b$ & $13.3 \mathrm{ab}$ & ND \\
\hline Botrytis cinerea & $51.6 \mathrm{bc}$ & ND & ND & ND & ND & ND \\
\hline Cladosporium cladosporioides & ND & ND & ND & ND & ND & $15.0 \mathrm{a}$ \\
\hline C. macrocarpum & $146.8 \mathrm{a}$ & $31.7 \mathrm{a}$ & $26.7 \mathrm{a}$ & $28.3 \mathrm{a}$ & $30.0 \mathrm{a}$ & $46.7 \mathrm{a}$ \\
\hline Coprinellus disseminatus & $4.5 \mathrm{~d}$ & ND & ND & ND & ND & ND \\
\hline Cutaneotrichosporon curvatus & ND & ND & ND & ND & $3.3 \mathrm{c}$ & ND \\
\hline Discosia sp. & $6.2 \mathrm{~d}$ & $3.3 c$ & ND & ND & ND & ND \\
\hline Exophiala xenobiotica & ND & $1.7 \mathrm{c}$ & ND & $1.7 \mathrm{~b}$ & ND & ND \\
\hline Fusarium lateritium & $5.0 \mathrm{~d}$ & ND & ND & ND & $5.0 \mathrm{bc}$ & $11.7 \mathrm{a}$ \\
\hline Microdochium seminicola & $13.3 \mathrm{~cd}$ & $5.0 \mathrm{c}$ & ND & ND & ND & ND \\
\hline Penicillium aurantiacobrunneum & $48.0 \mathrm{bc}$ & $6.7 \mathrm{c}$ & ND & ND & ND & ND \\
\hline P. brevicompactum & $33.3 \mathrm{bcd}$ & ND & $6.7 \mathrm{a}$ & ND & ND & ND \\
\hline P. crustosum & ND & $11.7 \mathrm{bc}$ & ND & $13.3 a b$ & ND & ND \\
\hline Phlebiopsis gigantea & $20.0 \mathrm{~cd}$ & ND & ND & ND & ND & ND \\
\hline Trichoderma citrinoviride & ND & ND & ND & ND & $6.7 \mathrm{bc}$ & ND \\
\hline Total & $391.7 A^{* *}$ & 103.3 C & $100.2 \mathrm{CD}$ & 86.7 D & 98.6 CD & 126.7D \\
\hline
\end{tabular}

a I - the outdoor air samples, II-VII - the indoor air samples;

${ }^{b}$ For each location, the number of fungal spores followed by the same letter are not statistically different, and others are (Tukey HSD test, $\alpha \leq 0.05$ ). Small letters indicate the differences

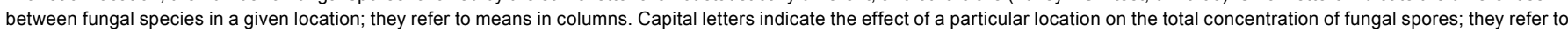
means in rows. 
sure, and atmospheric pollution, mainly by chemical particles (Niazi et al., 2015). Additionally, the presence of aeromycota in underground niches is closely related to the season of the year, the external environment, air currents, anthropogenic factors, and the presence of bats (Pusz et al., 2014, 2015 Kokurewicz et al., 2016; Ogórek et al., 2017; 2018).

This study is the first report of mycological air quality in the Demänovská Cave of Liberty. The external air of the cave was more contaminated by fungal propagules than the indoor air $\left(p_{1, v_{1}}<0.001\right)$, but aeromycota occurring in the underground sites is richer in species. Overall, we detected from 86.7 to 126.7 fungal spores per $\mathrm{m}^{3}$ of indoor air of the cave, and these values of fungal spore contaminations were similar to those in other Slovakian caves (Ogórek et al., $2016 \mathrm{~b}, \mathrm{c}, \mathrm{d})$. The highest number of airborne spores was discovered in Location VI, and the smallest number of spores was recorded in Locations IV $\left(p_{\mathrm{IV}, \mathrm{VI}}<0.001\right)$ (Tables. 1, 2). The concentration of fungal spores in the air is an important factor of biosafety, because elevated levels can have a negative effect on the health of people and animals (WHO, 1990; Choi et al., 1999).
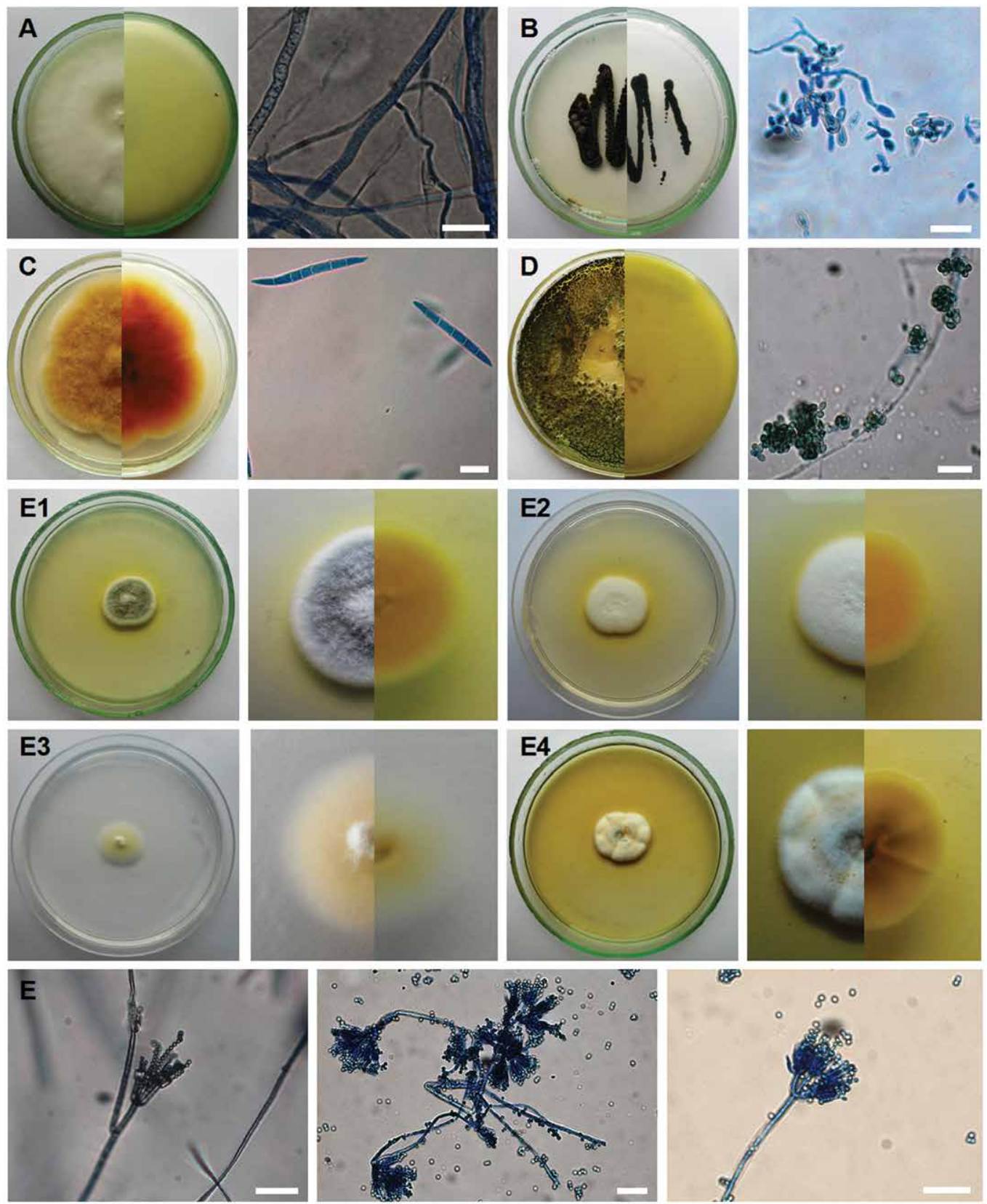

Figure 3. New airborne fungal species for underground sites discovered in Demänovská Cave of Liberty, 7-day-old (A, B, C, E) or 21-day-old culture (D) at $25 \pm 1^{\circ} \mathrm{C}$, top and bottom view of a colony on media PDA (A, B, C, D, E1), MEA (E2), Czapek-Dox Agar (E3), and CYA (E4), and the characteristic structure of fungi under the optical microscope on PDA: A - Bjerkandera adusta B - Exophiala xenobiotica, C Fusarium lateritium, D - Trichoderma citrinoviride, E - P. aurantiacobrunneum. Scale bars: A - D = 10 $\mu \mathrm{m}, \mathrm{E}=20 \mu \mathrm{m}$.
Currently, there are no official mycological air quality standards relating specifically to underground sites, but there are such requirements with respect to indoor air of buildings. Therefore, we could conclude that the mycological quality of air in the investigated sites does not pose a risk to human health with an unimpaired immune system, according to most standards of fungal air contamination, i.e. the American Industrial Hygiene Association, the World Health Organization, or the European Confederation Commission. For example, the most stringent standard among them states that the concentration of airborne fungi should not be higher than 500 spores per $\mathrm{m}^{3}$ (WHO, 1990; Choi et al., 1999). Thus, in this study, the numbers of airborne fungal spores were at much lower levels.

The species diversity of airborne fungi was higher in the air inside Demänovská Cave of Liberty than outside it (Tables. 1, 2). This trend is consistent with other reports on aeromycological research of underground sites during the summer (Pusz et al., 2014, 2015). Altogether, 18 different fungal spores were detected in the air samples of the cave. Fungal spores 
belonging to Bjerkandera adusta, Exophiala xenobiotica, Fusarium lateritium, Penicillium aurantiacobrunneum, and Trichoderma citrinoviride were discovered for the first time in underground sites (Tables. 1, 2; Fig. 3). The presence of these new species can be associated with anthropogenic factors, and the presence of bats in the Demänovská Cave of Liberty, because those factors can contribute to the qualitative and quantitative changes of fungal communities inhabiting underground areas (Griffin et al., 2014; Kokurewicz et al., 2016; Ogórek et al., 2016b).

Aerobiological investigations of mycobiota show that the fungal propagules of Cladosporium are most commonly detected in the atmosphere, as well as in the indoor air of underground sites (Larsen and Gravesen, 1991; Stępalska et al., 1999; Pusz et al., 2014). These spores also dominated in the air of Demänovská Cave of Liberty, especially C. macrocarpum spores $(p<0.001)$, which constituted for over $32 \%$ of all detected spores (Table 2 ). Cladosporium spores are one of the most allergenic biological particles in the air, which can cause allergic rhinitis, asthma or allergic alveolitis. However, almost 3,000 spores of this fungi in one cubic meter of air are required for the emergence of respiratory allergies in humans (Rapiejko et al., 2004). Therefore, the level of Cladosporium spores detected in the air samples of the Demänovská Cave of Liberty does not constitute a significant allergic risk to visitors, because we detected a maximum of 61.7 spores of Cladosporium in $1 \mathrm{~m}^{3}$ in the air of this cave.

An important group of the fungal community in the internal air of Demänovská Cave of Liberty constituted species belonging to Aspergillus and Penicillium (Tables. 1, 2), which are also commonly found in the bioaerosols of underground sites (Nováková, 2009; Vanderwolf et al., 2013). Their spores, as with the above-mentioned Cladosporium, are also strongly associated with allergic respiratory diseases, especially asthma (Pekkanen et al., 2007). Additionally, they can also cause opportunistic mycosis in mammals, including humans (Eschete et al., 1981; Hoffman et al., 1992). Overall, it should be noted that many of these fungal spores obtained from the Demänovská Cave of Liberty are not pathogenic. Still, some of them can pose a risk to persons with weakened immune systems (Nowicka, 2003).

\section{Conclusions}

Mycological monitoring carried out in underground ecosystems, with particular emphasis on sites open to tourists, or important from the point of view of wintering bats, is a relatively new venture. Regular monitoring will allow observation of qualitative and quantitative changes taking place in fungal communities inside underground ecosystems, and it will be possible to maintain biological safety for people and animals in such sites. The species diversity of airborne fungi was higher in the air inside the Demänovská Cave of Liberty than outside it, and Cladosporium macrocarpum spores dominated in this study. Moreover, research of this type has allowed the detection of new airborne species for underground ecosystems (Bjerkandera adusta, Exophiala xenobiotica, Fusarium lateritium, Penicillium aurantiacobrunneum, and Trichoderma citrinoviride).

Nevertheless, it is difficult to explain the occurrence of these new species. One of the reasons may be the accuracy of research methods, but it can also be associated with anthropogenic factors, as well as the presence of bats in this cave. Pearson correlation analysis showed that the levels of airborne fungal spores were correlated positively with air temperature. The concentration of fungi in the air of the investigated sites does not pose a health risk for people with an unimpaired immune system. However, some of the airborne fungi detected in the Demänovská Cave of Liberty can pose a risk to persons and animals with weakened immune systems or people who have fungal allergies. Moreover, it is likely that the mycological quality of air in these sites may deteriorate, which is why their further monitoring is important, and should be regularly performed.

\section{Acknowledgements}

This work was co-financed by the Ministry of Science and Higher Education, carried out by the University of Wroclaw "Grant to Young Researchers," Grant number: 0420/2299/17.

\section{References}

Barton, H.A., and Northup, D.E., 2007, Geomicrobiology in cave environments: past, current, and future perspectives: Journal of Cave and Karst Studies, v. 69, p. 163-178.

Bensch, K., Braun, U., Groenewald, J.Z., and Crous, P.W., 2012, The genus Cladosporium: Studies in Mycology, v. 72, p. 1-401. https://doi. org/10.3114/sim0003.

Brickus, L.S.R., Siqueira, L.F.G., Aquino Neto, F.R., and Cardoso, J.N., 1998, Occurrence of airborne bacteria and fungi in bayside offices in Rio de Janeiro, Brazil: Indoor and Built Environment, v. 7, p. 270-275. https://doi.org/10.1177/1420326X9800700504.

Bruce, N., Perez-Padilla, R., and Albalak, R., 2000, Indoor air pollution in developing countries: a major environmental and public health challenge: Bulletin of the World Health Organization, v. 78, no. 9, p. 1078-1092.

Chilvers, M.I., and du Toit, L.J., 2006, Detection and identification of Botrytis species associated with neck rot, scape blight, and umbel blight of onion: Online. Plant Health Progress, htttps://doi.org/10.1094/PHP-2006-1127-01-DG.

Choi, Y.W., Hyde, K.D., and Ho, W.H., 1999, Single spore isolation of fungi: Fungal Diversity, v. 3, p. 29-38.

Darçın, M., 2014, Association between air quality and quality of life: Environmental Science and Pollution Research, v. 21, p. 1954-1959. https:// doi.org/10.1007/s11356-013-2101-3. 
de Hoog, G.S., Zeng, J.S., Harrak, M.J., and Sutton, D.A., 2006, Exophiala xenobiotica sp. nov., an opportunistic, black, yeast- inhabiting environment, rich in hydrocarbons: Antonie van Leeuwenhoek, v. 90, no. 3, p. 257-68. https://doi.org/10.1007/s10482-006-9080-z.

Doyle, J.J., and Doyle, J.L., 1987, A rapid DNA isolation procedure for small quantities of fresh leaf tissue: Phytochemical Bulletin, v. 19 , p. 11-15.

Eschete, M.L., King, J.W., West, B.C., and Oberle, A., 1981, Penicillium chrysogenum endophthalmitis: first reported case: Mycopathology, v. 74, p. 125-127. https://doi.org/10.1007/BF01259468.

Frisvad, J.C., and Samson, R.A., 2004, Polyphasic taxonomy of Penicillium subgenus Penicillium A guide to identification of food and air-borne terverticillate Penicillia and their mycotoxins: Studies in Mycology, v. 49, p. 1-173.

Golubev, V.I., 1981, New combinations in the yeast genus Cryptococcus: Mikologiya i Fitopatologiya, v. 15, no. 6, p. 467-468.

Griffin, D.W., Gray, M.A., Lyles, M.B., and Northup, D.E., 2014, The transport of nonindigenous microorganisms into caves by human visitation: A case study at Carlsbad Caverns National Park: Geomicrobiology Journal, v. 31, no. 3, p. 175-185. https://doi.org/10.1080/01490451.2013.815 294.

Hernández-Restrepo, M., Groenewald, J.Z., and Crous, P.W., 2016. Taxonomic and phylogenetic re-evaluation of Microdochium, Monographella and Idriella: Persoonia, v. 36, p. 57-82. https://doi.org/10.3767/003158516X688676.

Hoffman, M., Bash, E., Berger, S.A., Burke, M., and Yust, I., 1992, Fatal necrotizing esophagitis due to Penicillium chrysogenum in a patient with acquired immunodeficiency syndrome: European Journal of Clinical Microbiology \& Infectious Diseases, v. 11, p. 1158-1160. https://doi. org/10.1007/BF01961135.

Houbraken, J., Frisvad, J.C., and Samson, R.A., 2011, Taxonomy of Penicillium section Citrina: Studies in Mycology, v. 70, p. 53-138. https://doi. org/10.3114/sim.2011.70.02

Jülich, W., 1979, Studies in resupinate Basidiomycetes - V. Some new genera and species: Persoonia, v. 10, no. 1, p. 137-140.

Jung, P.E., Fong, J.J., Park, M.S., Oh, S.-Y., Kim, C., and Lim, Y.W., 2014, Sequence validation for the identification of the White-Rot fungi Bjerkandera in public sequence databases: Journal of Microbiology and Biotechnology, v. 24, no. 10, p. 1313-1319. https://doi.org/10.4014/ jmb.1404.04021

Keirle, M.R., Hemmes, D.E., and Desjardin, D.E., 2004, Agaricales of the Hawaiian Islands. 8. Agaricaceae: Coprinus and Podaxis; Psathyrellaceae: Coprinopsis, Coprinellus and Parasola: Fungal Diversity, v. 15, p. 33-124.

Kim, J.Y., Kwon, H.W., Yun, Y.H., and Kim, S.H., 2016, Identification and characterization of Trichoderma species damaging shiitake mushroom bed-logs infested by Camptomyia Pest: Journal of Microbiology and Biotechnology, v. 26, no. 5, p. 909-917. https://doi.org/10.4014/ jmb.1602.02012.

Kokurewicz, T., Ogórek, R., Pusz, W., and Matkowski, K., 2016, Bats increase the number of cultivable airborne fungi in the "Nietoperek" bat reserve in Western Poland: Microbial Ecology, v. 72, no. 1, p. 36-48. https://doi.org/10.1007/s00248-016-0763-3.

Larsen, L., and Gravesen, S., 1991, Seasonal variation of outdoor airborne viable microfungi in Copenhagen, Denmark: Grana, v. 30 , p. $467-471$. https://doi.org/10.1080/00173139109432011

Mammas, I.N., and Spandidos, D.A., 2016, Paediatric virology in the hippocratic corpus: Experimental and Therapeutic Medicine, v. 12, p. 541-549. https://doi.org/10.3892/etm.2016.3420.

Marušin, M., 2003, Geological conditions - factor of origin of two different cave systems in two adjacent valleys (the Demänovská Valley and the Jánska Valley, the Low Tatras, Slovakia): Acta Carsologica, v. 32, no. 1, p. 121-130.

Niazi, S., Hassanvand, M.S., Mahvi, A.H., Nabizadeh, R., Alimohammadi, M., Nabavi, S., Faridi, S., Dehghani, A., Hoseini, M., Moradi-Joo, M., Mokamel, A., Kashani, H., Yarali, N., and Yunesian, M., 2015, Assessment of bioaerosol contamination (bacteria and fungi) in the largest urban wastewater treatment plant in the Middle East: Environmental Science and Pollution Research, v. 22, p. 16014-16021. https://doi. org/10.1007/s11356-015-4793-z.

Nováková, A., 2009, Microscopic fungi isolated from the Domica Cave system (Slovak Karst National Park, Slovakia). A review: International Journal of Speleology, v. 38, no. 1, p. 71-82. https://doi.org/10.5038/1827-806X.38.1.8.

Nowicka, J., 2003, Czynniki ryzyka, epidemiologia i klinika grzybic w ostrych białaczkach (Risk factors, epidemiology and clinics of mycoses in acute leukemia): Mikologia Lekarska, v. 10, p. 135-143 [In Polish].

Nudziková, L'., 2014, Vývoj návštevnosti sprístupnených jaskýň na Slovensku od roku 2009 (Course of show caves attendance in Slovakia since 2009): Aragonit, v. 19, no. 1-2, p. 35-38 [in Slovak].

Ogórek, R., 2018, Fungal Communities on Rock Surfaces in Demänovská Ice Cave and Demänovská Cave of Liberty (Slovakia): Geomicrobiology Journal, v. 35, no. 4, p. 266-276. https://doi.org/10.1080/01490451.2017.1348409.

Ogórek, R., Dyląg, M., and Kozak, B., 2016a, Dark stains on rock surfaces in Driny Cave (Little Carpathian Mountains, Slovakia): Extremophiles, v. 20, p. 641-652. https://doi.org/10.1007/s00792-016-0853-7.

Ogórek, R., Dyląg, M., Kozak, B., Višňovská, Z., Tančinová, D., and Lejman, A., 2016b, Fungi isolated and quantified from bat guano and air in Harmanecká and Driny Caves (Slovakia): Journal of Cave and Karst Studies, v. 78, no. 1, p. 41-49. https://doi.org/10.4311/2015MB0108.

Ogórek, R., Dyląg, M., Višňovská, Z., Tančinová, D., and Zalewski, D., 2016c, Speleomycology of air and rock surfaces in Driny Cave (Lesser Carpathians, Slovakia): Journal of Cave and Karst Studies, v. 78, no. 2, p. 119-127. https://doi.org/10.4311/2015MB0128.

Ogórek, R., Kozak, B., Lejman, A., Kalinowska, K., and Dyląg, M., 2012, Analiza genetyczna szczepów Candida albicans za pomocą techniki RFLP-PCR (Molecular typing of Candida albicans isolates using RFLP-PCR): Mikologi Lekarska, v. 9, no. 3, p. 109-114 [in Polish].

Ogórek, R., Kozak, B., Višňovská, Z., and Tančinová, D., 2018, Phenotypic and genotypic diversity of airborne fungal spores in Demänovská Ice Cave (Low Tatras, Slovakia): Aerobiologia, v. 34, no. 1, p. 13-28. https://doi.org/10.1007/s10453-017-9491-5.

Ogórek, R., Lejman, A., and Matkowski, K., 2013, The fungi isolated from the Niedźwiedzia Cave in Kletno (Lower Silesia, Poland): International Journal of Speleology, v. 42, no. 2, p. 161-166. https:// doi.org/10.5038/1827-806X.42.2.9.

Ogórek, R., Pusz, W., Zagożdżon, P.P., Kozak, B., and Bujak, H., 2017, Abundance and diversity of psychrotolerant cultivable mycobiota in winter of a former aluminous shale mine: Geomicrobiology Journal, v. 34, no. 10, p. 823-833. https://doi.org/10.1080/01490451.2017.1280860.

Ogórek, R., Višňovská, Z., and Tančinová, D., 2016d, Mycobiota of underground habitats: case study of Harmanecká Cave in Slovakia: Microbial Ecology, v. 71, no. 1, p. 87-99. https://doi.org/10.1007/s00248-015-0686-4.

Pekkanen, J., Hyvarinen, A., Haverinen-Shaughnessy, U., Korppi, M., Putus, T., and Nevalainen, A., 2007, Moisture damage and childhood asthma: a population-based incident case-control study: European Respiratory Society, v. 29, no. 3, p. 509-515. https://doi. org/10.1183/09031936.00040806.

Poulson, T.L., and White, W.B., 1969, The cave environment: Science, v. 165, no. 3897, p. 971-981. https://doi.org/10.1126/science.165.3897.971.

Pusz, W., Ogórek, R., Knapik, R., Kozak, B., and Bujak, H., 2015, The occurrence of fungi in the recently discovered Jarkowicka cave in the Karkonosze Mts. (Poland): Geomicrobiology Journal, v. 32, no. 1, p. 59-67. https://doi.org/10.1080/01490451.2014.925010. 
Ogórek

Pusz, W., Ogórek, R., Uklańska-Pusz, C., and Zagożdżon, P., 2014, Speleomycological research in underground Osówka complex in Sowie Mountains (Lower Silesia, Poland): International Journal of Speleology, v. 43, no. 1, p. 27-34. https://doi.org/10.5038/1827-806X.43.1.3.

Rampelotto, P.H., 2013, Extremophiles and extreme environments: Life, v. 3, no. 3, p. 482-485. https://doi.org/10.3390/life3030482.

Rapiejko, P., Lipiec, A., Wojdas, A., and Jurkiewicz, D., 2004. Threshold pollen concentration necessary to evoke allergic symptoms: International Review of Allergology and Clinical Immunology in Family Medicine, v. 10, p. 91-94.

Reynolds, S.J., Black, D.W., Borin, S.S., Breuer, G., Burmeister, L.F., Fuortes, L.J, Smith, T.F., Stein, M.A., Subramanian, P., Thorne, P.S., and Whitten, P., 2001, Indoor environmental quality in six commercial office buildings in the Midwest United States: Applied Occupational and Environmental Hygiene, v. 16, p. 1065-1077. https://doi.org/10.1080/104732201753214170.

Romagnoli, P., Balducci, C., Perilli, M., Vichi, F., Imperiali, A., and Cecinato, A., 2016, Indoor air quality at life and work environments in Rome, Italy: Environmental Science and Pollution Research, v. 23, no. 4, p. 3503-3516. https://doi.org/10.1007/s11356-015-5558-4.

Slovak Caves Administration, 2018, Demänovská Ice Cave, http://www.ssj.sk/en/jaskyna/5-demanovska-ice-cave, access: 25.01.2018.

Stępalska, D., Harmata, K., Kasprzyk, I., Myszkowska, D., and Stach, A., 1999, Occurrence of air borne Cladosporium and Alternaria spores in Southern and Central Poland in 1995-1996: Aerobiologia, v. 15, p. 39-47. https://doi.org/10.1023/A:1007536513836.

Stolwijk, J.A.J., 1991, Sick-Building Syndrome: Environmental Health Perspectives, v. 95, p. 99-10. https://doi.org/10.1289/ehp.919599.

Tanaka, K., Endo, M., Hirayama, K., Okane, I., Hosoya, T., and Sato, T., 2001, Phylogeny of Discosia and Seimatosporium, and introduction of Adisciso and Immersidiscosia genera nova: Persoonia, v. 26, p. 85-98. https://doi.org/10.3767/003158511X576666.

Tang, J.W., 2009, The effect of environmental parameters on the survival of airborne infectious agents: Journal of the Royal Society Interface, v. 6, no. 6, p. 737-746. https://doi.org/10.1098/rsif.2009.0227.focus.

Vanderwolf, K.J., Malloch, D., McAlpine, D.F., and Forbes, G.J., 2013, A world review of fungi, yeasts, and slime molds in caves: International Journal of Speleology, v. 42, no. 1, p. 77-96. https:// doi.org/10.5038/1827-806X.42.1.9.

Visagie, C.M., Varga, J., Houbraken, J., Meijer, M., Kocsubè, S., Yilmaz, N., Fotedar, R., Seifert, K.A., Frisvad, J.C., and Samson, R.A., 2014, Ochratoxin production and taxonomy of the yellow aspergilli (Aspergillus section Circumdati): Studies in Mycology, v. 78, p. 1-61. https://doi. org/10.1016/j.simyco.2014.07.001.

Vitale, S., Santori, A., Wajnberg, E., Castagnone-Sereno, P., Luongo, L., and Belisario, A., 2011, Morphological and molecular analysis of Fusarium lateritium, the cause of gray necrosis of hazelnut fruit in Italy: Phytopathology, v.101, no. 6, p. 679-86. https://doi.org/10.1094/PHYTO-04-10-0120.

White, T.J., Bruns, T., Lee, S., and Taylor, J.W., 1990, Amplification and direct sequencing of fungal ribosomal RNA genes for phylogenetics. in Innis, M.A., Gelfand, D.H., Sninsky, J.J., and White, T.J., ed., PCR Protocols: A Guide to Methods and Applications: New York, Academic Press, pp. 315-322. https://doi.org/10.1016/B978-0-12-372180-8.50042-1.

WHO, 1983, Indoor Air Pollutants: exposure and health effects. WHO EURO Reports and studies. Copenhagen: World Health Organization. Report No 1983:78.

WHO, 1990, Indoor Air Quality: Biological contaminants: report on a WHO meeting, Rautavaara, 29 August - 2 September 1988, WHO Regional Publications, European Series no. 31. WHO Regional Office for Europe, Copenhagan.

Zain, M.E., 2011, Impact of mycotoxins on humans and animals: Journal of Saudi Chemical Society, v. 15, no. 2, p. 129-144. https://doi. org/10.1016/j.jscs.2010.06.006. 